\title{
ANALISIS PERSIAPAN PT. BANK PEMBIAYAAN RAKYAT SYARIAH AL MAKMUR DALAM PENERAPAN GOOD CORPORATE GOVERNANCE
}

\author{
Hendra Putra' ${ }^{1}$ Zainuddin², Alimin ${ }^{3}$. \\ Corresponding Author's: Institut Agama Islam Negeri Batusangkar \\ e-mail: putrahendra166@Gmail.com \\ Copyright (C) 2021
}

+20 .

\begin{abstract}
The aim is to analyze the preparation of PT. Bank Pembiayaan Rakyat Syariah Al Makmur in implementing Good Corporate Governance (GCG) in the Awareness Building, GCG Assessment and Manual Building stages. The method used is descriptive qualitative, the data collection technique used by the writer is through interviews and documentation, Data processing was carried out by qualitative analysis then presented the data in a short narrative description, then analyzed and concluded. The Awareness Building stage has been done well, but it must be maximized more by providing education through seminars, workshops and group discussions sustainably. So that, all elements that involved have the same understanding and awareness of the importance of implementing GCG. For the GCG Assessment stage which carried out by the internal company is in accordance, but in determining the priority scale must pay attention to the internal conditions of the company. And for the Manual Building stage (preparation of guidelines) of PT. PT. Bank Pembiayaan Rakyat Syariah Al-Makmur has not completed the GCG.
\end{abstract}

Keywords: Implementasi, GCG, Awareness Building, GCG assessment, Manual Building

\section{PENDAHULUAN}

Krisis yang terjadi pada dunia perbankan di Indonesia yang dimulai akhir tahun 1997 bukan semata-mata akibat krisis ekonomi saja, tetapi juga diakibatkan karena belum dilaksanakannya Good Corporate Governance (untuk selanjutnya disebut GCG) dan etika yang melandasinya (Wahyudin Zarkasyi, 2008). Hal ini berdampak pada munculnya krisis kepercayaan oleh para investor dan calon investor untuk menginvestasikan dan menyimpan dananya di sebuah perusahaan ataupun lembaga keuangan perbankan.

Menurut konsep syariah, untuk mengembalikan kepercayaan tersebut, perusahaan ataupun lembaga keuangan perbankan harus mengelola usahanya dengan baik. Anjuran ini dalam Islam sudah dijelaskan bahwa usaha harus 
berjalan dengan governance yang baik, karena dipandang sebagai salah satu manifestasi dalam ibadah atau amal shalih yang didasarkan pada ketakwaan, sehingga diperlukan ketaatan pada asas spiritual dan operasional. Dengan harapan akan mendapatkan keberkahan, kemanfaatan dan kesinambungan (sustainability) dalam kehidupan duniawi, disamping menjadi kegiatan yang dapat dipertanggungjawabkan kepada Allah Swt (Governance K. N., 2011).

Menurut konsep yuridis, salah satu cara yang bisa dijalankan adalah dengan melaksanaan GCG dengan pengawasan yang efektif dari Otoritas Pengawas Bank, hal ini diungkapkan dalam Pedoman Good Corporate Governance Perbankan Indonesia yang dikeluarkan oleh Komite Nasional Kebijakan Corporate Governance Indonesia pada Januari 2004 (Governance K. N., 2004).

GCG menjadi sebuah keharusan untuk dijalankan dalam dunia perbankan semenjak dikeluarkannya Peraturan Bank Indonesia nomor 8/4/PBI/2006 untuk bank umum, sementara itu untuk Bank Umum Syariah tertuang pada Peraturan Bank Indonesia Nomor 11/33/PBI/2009 yang dikeluarkan tanggal 29 Januari 2009. Pada tanggal 10 Desember 2018, Otoritas Jasa Keuangan mengeluarkan peraturan nomor 24/POJK.03/2018 yang membahas tentang Penerapan Tata Kelola bagi Bank Pembiayaan
Rakyat Syariah Indonesia (OJK, 2018). Pada tanggal 28 Juni 2019 dikeluarkan Surat Edaran OJK Nomor 13/SEOJK.03/ 2019 yang mengatur tentang pelaksanaan Tata Kelola perusahaan bagi BPRS. Dalam surat edaran ini dijelakan bahwa tata kelola yang baik adalah suatu tata cara pengelolaan BPRS yang menerapkan prinsip-prinsip keterbukaan, akuntabilitas, pertanggungjawaban, profesional dan kewajaran (OJK, 2019).

Menurut Chinn (2000) dan Shaw (2003) dalam (Harjanti 2018) Perusahaan yang telah berhasil dalam mengimplementasikan GCG umumnya menggunakan tiga tahapan, antara lain tahap persiapan, tahap implementasi, dan tahap evaluasi. Tahap persiapan terdiri atas awerness building, GCG assessment, dan GCG manual building. Tahap implementasi terdiri atas sosialisasi, implementasi, dan internalisasi. Sedangkan tahap evaluasi merupakan tahapan yang perlu dilakukan secara teratur dari waktu ke waktu untuk mengukur sejauh mana efektivitas penerapan GCG telah dilakukan (Harjanti, 2018).

Senada dengan itu, dalam bisnis syariah, agar pelaksanaan Good Governance Bisnis Syariah dapat berjalan efektif, diperlukan proses keikutsertaan semua pihak dalam perusahaan. Dengan menjalankan beberapa tahapan, di antaranya membangun pemahaman, kepedulian dan komitmen, melakukan kajian terhadap 
kondisi perusahaan, menyusun program dan pedoman pelaksanaan, melakukan internalisasi serta penilaian sendiri serta menyediakan semua informasi yang terkait dengan pelaksanaan Good Governance Bisnis Syariah (Governance K. N., 2011).

Berdasarkan latar belakang masalah ini, yang menjadi fokus penelitian penulis adalah persiapan Bank Pembiayaan Rakyat Syariah dalam Penerapan Good Corporate Governance (GCG) dengan penelitian pada PT. BPR Syariah Al Makmur, dengan pertanyaan penelitian bagaimana persiapan PT. BPR Syariah Al Makmur dalam Penerapan Good Corporate Governance (GCG) pada tahap awareness Building, tahap GCG assessment dan tahap manual Building.

\section{KAJIAN TEORI}

\section{Good Corporate Governance (GCG)}

Forum for Corporate Governance in Indonesia (FCGI) mendefinisikan GCG sebagai seperangkat aturan yang menetapkan hubungan antara pemegang saham, pengurus, pihak dikreditur, pemerintah, karyawan, serta para pemegang kepentingan intern dan ekstern lainnya sehubungan dengan hak-hak dan kewajibannya (Arifin, 2005).

Muhammad Djumhana mengata kan bahwa sebenarnya GCG merupakan bentuk pengaturan internal dalam suatu badan usaha (self regulation), yang bertujuan untuk meningkatkan nilai pemegang saham (shareholders value) serta mengakomodasi berbagai pihak yang berkepentingan dengan perusahaan (stakeholders). Menurut Bank Dunia, definisi GCG adalah aturan, standar, dan organisasi dibidang ekonomi yang mengatur prilaku pemilik perusahaan, direktur dan manajer serta perincian dan penjabaran tugas dan wewenang serta pertanggungjawabannya kepada investor (pemegang saham dan kreditur) (Usman, 2014). Dalam peraturan Bank Indonesia, GCG diterjemahkan sebagai suatu tata kelola Bank yang menerapkan prinsip-prinsip keterbukaan, akuntabilitas, pertanggungjawaban, independensi, dan kewajaran (BI, 2006).

Pengertian di atas dalam konteks perbankan dapat diartikan bahwa GCG adalah suatu tata kelola usaha perbankan yang sehat yang berlandaskan kepada transparansi (transparancy), akuntabilitas (accountability), pertanggungjawaban (responsibility), independensi (independency), dan kewajaran (fairness). Sehingga dapat meningkatkan kinerja bank, melindungi kepentingan stakeholders serta meningkatkan kepatuhan terhadap peraturan perundang-undangan yang berlaku serta nilai-nilai etika (code of conduct) yang berlaku umum pada industri perbankan.

\section{Prinsip-Prinsip Good Corporate Governance (GCG)}

Konsep syariah, pedoman pelaksanaan bisnis dicontohkan oleh Nabi 
Muhammad SAW yang tergambar dari sifat dan perilaku beliau yaitu shiddiq, fathonah, amanah, dan tabligh. (Governance K. N., 2011) Keempat sifat ini merupakan satu kesatuan yang tidak dapat dipisahkan satu dengan yang lainnya dan merupakan salah satu perwujudan dari iman dan takwa.

Menurut konsep yuridis, secara umum terdapat lima prinsip dasar dari GCG yaitu keterbukaan (transparency) bank harus mengungkapkan informasi secara tepat waktu, akurat dan dapat diperbandingkan serta mudah diakses oleh stakeholders, yang meliputi hal-hal yang berkatan dengan visi, misi, sasaran usaha dan strategi perusahaan, kondisi keuangan, susunan dan kompensasi pengurus, pemegang saham pengendali, pejabat eksekutif, pengelolaan risiko, sistem pengawasan dan pengendalian intern, status kepatuhan, sistem dan pelaksanaan GCG serta kejadian penting yang dapat mempengaruhi kondisi bank, dengan tetap menjaga rahasia bank sesuai dengan peraturan perundang-undangan yang berlaku. Semua kebijakan bank harus tertulis dan dikomunikasikan kepada pihak yang berkepentingan dan yang berhak memperoleh informasi tentang kebijakan tersebut.

Akuntabilitas (accountability), bank harus menetapkan tanggung jawab yang jelas dari masing-masing organ organisasi yang selaras dengan visi, misi, sasaran usaha dan strategi perusahaan, serta mempunyai kompe- tensi sesuai dengan tanggung jawabnya dan memahami perannya dalam pelaksanaan GCG. Bank harus memiliki ukuran kinerja dari semua jajaran bank berdasarkan ukuran-ukuran yang disepakati konsisten dengan nilai perusahaan (corporate values), sasaran usaha dan strategi bank serta memiliki rewards and punishment system, dengan tetap memastikan terdapatnya check an balance system dalam pengelolaan bank.

TanggungJawab (responsibility), untuk menjaga kelangsungan usahanya, bank harus berpegang pada prinsip kehati-hatian (prudential banking practices) dan menjamin dilaksanakannya ketentuan yang berlaku, serta bertindak sebagai good Corporate citizen (perusahaan yang baik) termasuk peduli terhadap lingkungan dan melaksanakan tanggung jawab social.

Independensi (independency), bank harus menghindari terjadinya dominasi yang tidak wajar oleh stakeholder dan tidak terpengaruh oleh kepentingan sepihak serta bebas dari benturan kepentingan (conflict of interest). Serta harus tetap harus objektif dan bebas dari segala tekanan dari pihak manapun dalam pengambilan keputusan.

Kewajaran (fairness), bank harus senantiasa memperhatikan kepentingan seluruh stakeholders berdasarkan azas kesetaraan dan kewajaran (equal treatment). Dengan memberikan kesempatan kepada seluruh stakeholders 
untuk memberikan masukan dan menyampaikan pendapat bagi kepentingan bank serta mempunyai akses terhadap informasi sesuai dengan prinsip keterbukaan. (Governance K. N., 2004).

\section{Tujuan Penerapan Good Corporate Governance (GCG)}

Pada peraturan Bank Indonesia Nomor 8/14/PBI/2006, dapat diketahui bahwa yang menjadi tujuan penerapan GCG bagi Bank Umum yaitu meningkatkan kinerja Bank Umum, melindungi kepentingan seluruh pihak yang memiliki kepentingan secara langsung atau tidak langsung terhadap kegiatan usaha bank umum (stakeholders), meningkatkan kepatuhan terhadap peraturan-peraturan yang berlaku serta nilai-nilai etika (code of conduct) yang berlaku umum pada industri perbankan, memperkuat kondisi internal perbankan nasional sesuai dengan API (Arsitektur Perbankan Indonesia).(BI, 2006).

Sementara itu, dari Peraturan Bank Indonesia Nomor 11/33/PBI/2009 dan Surat Edaran Bank Indonesia Nomor 12/13/DPbS tanggal 30 April 2010, dapat diketahui yang menjadi tujuan penerapan GCG bagi Bank Umum Syariah dan Unit Usaha Syariah (UUS) yaitu mewujudkan tata kelola industri perbankan syariah yang berlandaskan transparansi, akuntabilitas, pertanggungjawaban, profesional, dan kewajaran, membangun industri perbankan yang sehat dan tangguh. memenuhi prinsip syariah, sehingga reputasi industri perbankan syariah tetap terjaga, meningkatkan pelindungan seluruh pihak yang memiliki kepentingan secara langsung maupun tidak langsung terhadap kegiatan usaha dan kelangsungan usaha perbankan syariah. meningkatkan kepatuhan terhadap peraturan perundang-undangan yang berlaku serta nilai-nilai etika yang berlaku secara umum pada industri perbankan syariah dalam rangka melakukan check and balance di antara kelembagaan perbankan syariah. (BI, 2010)

\section{Tahapan-Tahapan Penerapan GCG}

Menurut Chinn (2000) dan Shaw (2003), tahapan-tahapan dalam proses penerapan GCG ada tiga tahapan, yang pertama tahap persiapan, dalam tahap persiapan ini, terdapat tiga langkah yang harus dilakukan antara lain Awareness Building (membangun kesadaran), untuk membangun kesadaran tentang urgensi GCG ini merupakan tanggung jawab bersama, yang melibatkan semua pihak yaitu semua anggota Direksi dan Dewan Komisaris, Dewan Pengawas Syariah, serta Pemegang Saham Pengendali, dan semua karyawan. salah satu upaya ini dapat dilakukan adalah dengan memberikan edukasi melalui seminar, lokakarya dan diskusi kelompok secara berkesinambungan, dengan meminta bantuan tenaga ahli independen dari luar perusahaan yang menguasai teori tentang GCG. Sehingga diharapkan 
semua pihak yang terkait dengan perusahaan memiliki komitmen bahwa penerapan GCG adalah sebuah kebutuhan, bukan sebatas pemenuhan peraturan saja.

GCG assessment (penilaian) adalah upaya dalam memetakan kondisi perusahaan dalam penetapan GCG saat ini, yang dilakukan oleh internal perusahaan. Proses ini dilakukan bertujuan untuk memastikan level awal penerapan GCG dan untuk mengidentifikasi langkah yang tepat dalam mempersiapkan infrastruktur dan struktur perusahaan yang kondusif bagi penerapan GCG secara efektif. Dengan kata lain, GCG assessment dibutuhkan untuk mengidentifikasi aspek-aspek yang perlu mendapatkan perhatian terlebih dahulu, dan langkah apa yang dapat diambil untuk mewujudkannya.

Manual Building (penyusunan pedoman), merupakan penyusunan pedoman implementasi GCG setelah langkah GCG Assessment dilakukan. Berdasarkan hasil pemetaan tingkat kesiapan perusahaan dan upaya identifikasi prioritas penerapannya, penyusunan manual atau pedoman implementasi GCG dapat dilakukan.

Tahap Yang kedua yaitu tahap implementasi, terdapat tiga langkah utama yaitu sosialisasi yakni proses memperkenalkan GCG kepada seluruh bagian dari perusahaan perihal berbagai aspek yang terkait dengan implementasi GCG khususnya mengenai pedoman penerapan GCG. Upaya ini perlu dilakukan oleh suatu tim khusus yang sengaja dibentuk serta langsung berada di bawah pengawasan direktur utama atau salah satu direktur yang ditunjuk sebagai GCG champion di perusahaan. Tahap implementasi yakni kegiatan yang dilakukan harus sejalan dengan pedoman GCG yang sudah ada. berdasar roadmap yang telah disusun. Implementasi harus bersifat top down approach yang melibatkan dewan komisaris serta direksi perusahaan. Dan diharapakan Implementasi hendaknya mencakup pula upaya manajemen perubahan (change management) guna mengawal proses perubahan yang ditimbulkan oleh implementasi GCG. Tahap internalisasi merupakan tahapan jangka panjang dalam implementasi GCG, mencakup upaya memperkenalkan GCG di dalam seluruh proses bisnis perusahaan dan berbagai peraturan perusahaan lainnya. Dengan upaya ini diharapkan dapat dipastikan bahwa penerapan GCG bukan sekedar suatu kepatuhan yang bersifat superficial, tetapi benar-benar diwujudkan dan tercermin dalam seluruh aktivitas perusahaan.

Tahap yang ketiga tahap evaluasi, merupakan tahapan yang dilakukan secara teratur dan terus menerus dari waktu ke waktu untuk mengukur sejauh mana penerapan GCG telah dilakukan dengan meminta pihak independen melakukan audit implementasi dan scoring atas praktik GCG yang ada. (Harjanti, 2018). 
Dalam Pedoman Umum

Governance Bisnis Syariah yang disusun

oleh Komite Nasional Kebijakan governance agar pelaksanaan Good

Governance Bisnis Syariah dapat berjalan efektif, diperlukan proses keikutsertaan semua pihak dalam perusahaan. Untuk itu diperlukan beberapa tahapan yaitu pertama membangun pemahaman, kepedulian dan komitmen untuk pelaksanakan Good Governance Bisnis Syariah (GGBS) oleh semua anggota Direksi dan Dewan Komisaris, Dewan Pengawas Syariah, serta Pemegang Saham Pengendali, dan semua karyawan. Kedua melakukan kajian terhadap kondisi perusahaan yang berkaitan dengan pelaksanaan GGBS dan tindakan korektif yang diperlukan. Menyusun program dan pedoman pelaksanaan GGBS perusahaan. Ketiga melakukan internalisasi pelaksanaan GGBS sehingga terbentuk rasa memiliki dari semua pihak dalam perusahaan, serta pemahaman atas pelaksanaan pedoman GGBS dalam kegiatan sehari-hari. Keempat melakukan penilaian sendiri atau dengan menggunakan jasa pihak eksternal yang independen untuk memastikan penerapan GGBS secara berkesinambungan. Hasil penilaian tersebut diungkapkan dalam laporan tahunan dan dilaporkan dalam RUPS tahunan. Kelima menyediakan informasi yang memungkinkan para pemangku kepentingan untuk melakukan penilaian secara berkala terhadap pelaksanaan GGBS. (Governance K. N., 2011).

\section{Pelaksanaan Good Corporate Governance (GCG) Bank Pembiayaan Rakyat Syariah.}

Dalam Peraturan Otoritas Jasa Keuangan Nomor 24/POJK.03/2018, yang tertuang dalam pasal 2 ayat 2 bahwa BPRS wajib menerapkan tata kelola yang baik yang diwujudkan dalam beberapa hal yaitu pertama, pelaksanaan tugas dan tanggung jawab Direksi, Adapun tugas dan tanggung jawab Direksi adalah bertanggung jawab atas pelaksanaan kepengurusan BPRS, wajib melakukan pengelolaan BPRS sesuai dengan kewenangan dan tanggung jawab Direksi, pengelolaan BPRS harus memenuhi prinsip kehatihatian dan Prinsip Syariah. (OJK, 2018).

Kedua, Pelaksanaan tugas dan tanggung jawab Dewan Komisaris. Dewan Komisaris wajib melaksanakan tugas dan tanggung jawab sesuai dengan tata kelola yang baik, yaitu wajib memastikan penerapan Tata Kelola yang baik terselenggara, wajib melaksanakan pengawasan terhadap pelaksanaan tugas serta tanggung jawab Direksi serta memberikan nasihat kepada Direksi, dalam melaksanakan pengawasan atas pelaksanaan tugas dan tanggung jawab, Dewan Komisaris wajib mengarahkan, memantau, dan mengevaluasi pelaksanaan kebijakan strategis BPRS, dalam melaksanakan pengawasan atas pelaksanaan tugas dan tanggung jawab 
Direksi, Dewan Komisaris dilarang ikut serta dalam pengambilan keputusan mengenai kegiatan BPRS, kecuali terkait dengan penyediaan dana kepada pihak terkait, pengambilan keputusan merupakan bagian dari tugas pengawasan Dewan Komisaris.

Ketiga, Pelaksanaan tugas dan tanggung jawab DPS. Tugas dan Tanggung Jawab Dewan Pengawas Syariah antara lain adalah memberikan nasihat dan saran kepada Direksi serta mengawasi kegiatan BPRS agar sesuai dengan Prinsip Syariah, mengevaluasi kebijakan dan SOP BPRS agar sesuai dengan Prinsip Syariah, mengawasi proses pengembangan produk baru BPRS. meminta fatwa kepada Dewan Syariah Nasional Majelis Ulama Indonesia, melakukan evaluasi secara berkala. meminta data dan informasi terkait dengan aspek syariah dari setiap satuan kerja di BPRS untuk pelaksanaan tugasnya.

Keempat, Kelengkapan dan pelaksanaan tugas atau fungsi komite, yaitu Komite Audit, Komite Audit adalah sebuah komite yang membantu pelaksanaan tugas dan tanggung jawab Dewan Komisaris terkait dengan audit. kemudian Komite Pemantau Risiko, Komite Pemantau Risiko adalah sebuah komite yang membantu pelaksanaan tugas dan tanggung jawab Dewan Komisaris terkait dengan penerapan manajemen risiko. dan Komite Remunerasi dan Nominasi, Remunerasi adalah imbalan yang ditetapkan dan diberikan kepada anggota Direksi, anggota Dewan Komisaris, anggota DPS, dan/atau pegawai baik yang bersifat tetap maupun variabel dalam bentuk tunai maupun tidak tunai sesuai dengan tugas, wewenang, dan tanggung jawabnya, sedangkan Komite Remunerasi dan Nominasi adalah komite yang membantu pelaksanaan tugas dan tanggung jawab Dewan Komisaris terkait dengan Remunerasi dan nominasi.

Kelima, Pelaksanaan Prinsip Syariah dalam kegiatan BPRS. Ketentuan yang mengatur pelaksanaan prinsip syariah dalam kegiatan BPRS ini tertuang dalam PBI Nomor 9/19/PBI/2007 tentang pelaksanaan prinsip syariah dalam kegiatan penghimpunan dana dan penyaluran dana serta pelayanan jasa bank syariah yang dikeluarkan pada tanggal 17 Desember 2007.

Keenam, Penanganan benturan kepentingan.Dalam hal terjadi benturan kepentingan, anggota Direksi, anggota Dewan Komisaris, dan Pejabat Eksekutif dilarang mengambil tindakan yang dapat merugikan atau mengurangi keuntungan BPRS. BPRS wajib memastikan ketersediaan dan kecukupan pelaporan intern yang didukung oleh sistem infomasi manajemen yang memadai, BPRS harus memiliki dan menerapkan kebijakan intern mengenai benturan kepentingan (OJK, 2018).

Ketujuh Penerapan fungsi kepatuhan, audit intern, dan audit ekstern. Untuk memastikan kepatuhan, 
BPRS wajib memiliki anggota Direksi yang membawahkan fungsi kepatuhan. Untuk membantu pelaksanaan tugas anggota Direksi yang membawahkan fungsi kepatuhan, BPRS wajib menunjuk Pejabat Eksekutif yang independen terhadap operasional BPRS untuk bertanggung jawab terhadap pelaksanaan fungsi kepatuhan yang bertanggung jawab langsung kepada anggota Direksi yang membawahkan fungsi kepatuhan (OJK, 2018). Untuk Fungsi Audit Intern, Satuan kerja audit intern atau Pejabat Eksekutif yang bertanggung jawab terhadap pelaksanaan fungsi audit intern memiliki tugas dan tanggung jawab untuk membantu tugas direktur utama dan Dewan Komisaris dalam melakukan pengawasan operasional BPRS yang mencakup perencanaan, pelaksanaan, dan pemantauan hasil audit. Untuk Fungsi Audit Ekstern, BPRS wajib menunjuk akuntan publik dan kantor akuntan publik yang terdaftar di Otoritas Jasa Keuangan dalam pelaksanaan audit laporan keuangan tahunan BPRS, yang mengacu pada Peraturan Otoritas Jasa Keuangan mengenai penggunaan jasa akuntan publik dan kantor akuntan publik dalam kegiatan jasa keuangan serta peraturan perundang-undangan mengenai transparansi kondisi keuangan BPRS.

Kedelapan, Penerapan manajemen risiko, sistem pengendalian intern. Manajemen Risiko adalah serangkaian metodologi dan prosedur yang diguna- kan untuk mengidentifikasi, mengukur, memantau, dan mengendalikan Risiko yang timbul dari seluruh kegiatan usaha BPRS (OJK, 2018). Dalam POJK Nomor 23/P0JK.03/2018 kewajiban wajib menerapkan Manajemen Risiko secara efektif tertuang dalam pasal 2 yang mencakup pada empat aspek, Pengawasan aktif Direksi, Dewan Komisaris, dan Dewan Pengawas Syariah. Kecukupan kebijakan dan prosedur Manajemen Risiko serta penetapan limit Risiko. Kecukupan proses identifikasi, pengukuran, pemantauan, dan pengendalian Risiko serta sistem informasi Manajemen Risiko. Sistem pengendalian intern yang menyeluruh.

Ketentuan lebih lanjut ketentuan tetang manajemen risiko untuk BPRS tertuang dalam POJK nomor 23/0JK.3/2018 dan SEOJK Nomor XXX/SEOJK.03/2019 tentang tentang penerapan manajemen risiko bagi Bank Pembiayaan Rakyat Syariah.

Kesembilan, Batas maksimum penyaluran dana. Pelaksanaan penyaluran tertuang dalam PBI 13/5/PBI/2011 tentang batas maksimum penyaluran dana Bank Pembiayaan Rakyat Syariah, Batas Maksimum Penyaluran Dana atau BMPD adalah persentase maksimum realisasi penyaluran dana yang diperkenankan terhadap modal BPRS (BI, 2011). Dalam PBI 13/5/PBI/2011, pasal 5 menyatakan bahwa: "Penyaluran Dana kepada seluruh Pihak 
Terkait ditetapkan paling tinggi 10\% (sepuluh persen) dari Modal BPRS".

Kesepuluh, Rencana bisnis BPRS.

Rencana Bisnis adalah dokumen tertulis yang menggambarkan rencana pengembangan dan kegiatan usaha BPR atau BPRS dalam jangka waktu tertentu serta strategi untuk merealisasikan rencana tersebut sesuai target dan waktu yang ditetapkan dan laporan realisasi rencana bisnis adalah laporan yang disusun oleh Direksi BPR atau BPRS mengenai realisasi rencana bisnis sampai dengan periode tertentu, sedangkan laporan pengawasan rencana bisnis adalah laporan yang disusun oleh Dewan Komisaris BPR atau BPRS mengenai hasil pengawasan yang bersangkutan terhadap pelaksanaan rencana bisnis sampai dengan periode tertentu (OJK, 2016).

Kesebelas, Transparansi kondisi keuangan dan nonkeuangan. Kewajiban transparansi kondisi keuangan BPRS tertuang dalam PBI Nomor 7/47/PBI/2005 tentang Transparansi Kondisi Keuangan Bank Perkreditan Rakyat Syariah yang dikeluarkan pada tangga 14 November 2005. PBI menjelaskan bahwa BPRS wajib membuat dan menyajikan laporan keuangan dengan bentuk dan cakupan, yang terdiri dari Laporan Tahunan, Laporan Keuangan Publikasi Triwulanan.

\section{METODE PENELITIAN}

Penelitian ini merupakan penelitian lapangan (field research) yang menjadikan data-data di PT. Bank Pembiayaan Rakyat Syariah Al-Makmur sebagai acuan utama. dengan pendekatan kualitatif, Sumber data yang digunakan dalam penelitian ini adalah sumber data primer dan sumber data sekunder. Sumber data primer dalam penelitian ini adalah pihak-pihak di PT. BPR Syariah Al Makmur. Sedangkan sumber data sekunder dalam penelitian ini adalah dokumen dan data tertulis lainya pada PT. BPR Syariah Al Makmur yang berhubungan dengan persiapan PT. Bank Pembiayaan Rakyat Syariah Al Makmur dalam Penerapan Good Corporate Governance (GCG). Teknik pengumpulan data yang dilakukan adalah dengan wawancara dan dokumentasi.

Analisis data dalam penelitian ini dimulai sejak sebelum memasuki lapangan, selama di lapangan, dan setelah selesai di lapangan, menggunakan analisis data kualitatif dengan konsep Miles and Huberman, dengan tahapan sebagai berikut (Sugiyono, 2012) Reduksi Data, Penyajian Data, Penarikan Kesimpulan dan Verifikasi. Penarikan kesimpulan dilakukan dengan membandingkan fakta yang terjadi di lapangan dengan teori Chinn (2000) dan Shaw (2003), serta peraturan 0JK Nomor 24/POJK.03/2018.

Teknik Penjaminan Keabsahan Data dalam penelitian ini penulis menggunakan triangulasi teknik dan waktu (Sugiyono, 2012), data yang diperoleh melalui wawancara kemudian dicek dengan dokumentasi 
atau berkas yang berkaitan di waktu yang berbeda.

\section{HASIL DAN PEMBAHASAN}

Persiapan PT. Bank Pembiayaan Rakyat Syariah Al-Makmur Dalam Penerapan Good Corporate Governance (GCG)

Dalam tahap persiapan ini, terdapat tiga langkah yang harus dilakukan antara lain Awareness Building (membangun kesadaran). GCG Assessment (penilaian). Manual Building (penyusunan pedoman).

Ketiga tahap ini sudah dijalankan oleh PT. Bank Pembiayaan Rakyat Syariah Al Makmur, berdasarkan hasil wawancara yang dilakukan dengan pihak PT. Bank Pembiayaan Rakyat Syariah Al Makmur diperoleh data bahwa dalam membangun kesadaran (awereness building), seluruh pihak baik itu anggota direksi, dewan komisaris, dewan pengawas syariah, pemengang saham serta karyawan perusahaan sudah mengetahui bahwa adanya pelaksanaan GCG. Hal ini terbukti dengan telah dilakukannya upaya memperkenalkan GCG kepada semua pihak PT. Bank Pembiayaan Rakyat Syariah Al Makmur berupa edukasi yang bersifat internal terutama sekali upaya pengenalan akan arti penting penerapan GCG bagi perusahaan, sehingga diharapkan dengan dilakukannya edukasi ini menimbulkan kesadaran untuk mengaplikasikannya (Yasri. R.A, wawancara, 19 Juni 2020).
Secara prinsip GCG sebagian sudah diterapkan, namun dengan dikeluarkannya Peraturan Otoritas Jasa Keuangan Nomor 24/POJK.03/2018, sehingga penerapannya menjadi semakin terarah dan terkelola dengan lebih baik sehingga dapat ditingkatkan lagi, dengan terus menerus memberikan edukasi yang bersifat internal. Tolak ukur kesadaran semua pihak pada PT. Bank Pembiayaan Rakyat Syariah Al Makmur tentang arti pentingnya pelaksanaan GCG terlihat dari sudah terdapatnya tata tertib kerja masingmasing bagian, dan semua pihak komitmen sarta memetuhi tata tertib tersebut sebagai acuan dalam perkerjaannya (Yasri. R.A, wawancara, 19 Juni 2020).

Melihat dari tingginya tingkat kesadaran seluruh unsur yang terlibat dalam pelasanaan GCG, PT. Bank Pembiayaan Rakyat Syariah Al Makmur berkesimpulan bahwa seluruh pihak PT. Bank Pembiayaan Rakyat Syariah Al Makmur memiliki keinginan dan komitmen yang sangat besar dalam menjalankan GCG, hal ini tercermin dari sikap pihak PT. Bank Pembiayaan Rakyat Syariah Al Makmur yang menyadari bahwa GCG sebagai salah satu unsur yang harus dijalakan dengan baik apabila perusahaan ingin terus bertahan (Yasri. R.A, wawancara, 19 Juni 2020).

Dalam proses GCG Assessment (penilaian), sebagai langkah awal, manajemen sudah memetakkan kondisi perusahaan dengan mengidentifikasi 
aspek-aspek apa saja yang mendapatkan perhatian terlebih dahulu dengan menyusun skala prioritas dalam penerapan Good corporate governance (GCG) yang tertuang dalam rencana tindak untuk semester pertama, yang dilakukan langsung oleh dewan komisaris dan direksi, Poin ini menjadi prioritas dikarekan bahwa menurut pihak PT. Bank Pembiayaan Rakyat Syariah Al Makmur bahwa semua poin tersebut merupakan pondasi awal untuk penerapan GCG, langkah yang dilakukan adalah dengan membuat "time schedule" untuk masing-masing poin yang tertuang dalam rencana tindak semester pertama, dan juga terus melakukan evaluasi secara berkesinambungan (Yasri. R.A, wawancara, 19 Juni 2020).

Setelah penilaian dilakukan, langkah selanjutnya adalah Manual Building GCG, pihak PT. Bank Pembiayaan Rakyat Syariah Al Makmur dalam menyusun pedoman GCG berpedoman kepada Peraturan Otoritas Jasa Keuangan Nomor 24/POJK.03/ 2018 Tentang Penerapan Tata Kelola bagi Bank Pembiayaan Rakyat Syariah serta Surat Edaran OJK Nomor 13/SEOJK.03/2019 yang mengatur tentang pelaksanaan Tata Kelola perusahaan bagi BPRS. Untuk pedoman itu sendiri masih dalam tahap penyusunan secara lebih terperinci yang nantinya segera diimplementasikan setelah pedoman tersebut disahkan. Pihak PT. Bank Pembiayaan Rakyat Syariah Al Makmur optimis pedoman implementasi yang disusun nantinya akan membatu melahirkan tata kelola yang baik terhadap PT. Bank Pembiayaan Rakyat Syariah Al Makmur (Yasri. R.A, wawancara, 19 Juni 2020).

\section{Analisis Persiapan PT. Bank Pembiayaan Rakyat Syariah Al- Makmur Dalam Penerapan Good Corporate Governance (GCG)}

Good corporate governance (GCG) adalah suatu tata kelola usaha industri perbankan yang sehat yang berlandaskan kepada lima prinsip dasar pengelolaan perbankan, yaitu transparansi (transparancy), akuntabilitas (accountability), pertanggungjawaban (responsibility), independensi (independency), dan kewajaran (fairness), Sehingga dapat meningkatkan kinerja bank, melindungi kepentingan stakeholders serta meningkatkan kepatuhan terhadap peraturan perundang-undangan yang berlaku serta nilai-nilai etika (code of conduct) yang berlaku umum pada industri perbankan. Ada dua hal yang ditekankan dalam konsep ini. Pertama, pentingnya hak pemegang saham untuk memperoleh informasi dengan benar dan tepat pada waktunya. Kedua, kewajiban perusahaan untuk melakukan pengungkapan (disclosure) secara akurat, tepat waktu, transparan terhadap semua informasi kinerja perusahaan, kepemilikan, dan stakeholder.

Pengelolaan perusahaan dalam dunia perekonomian adalah sebuah keharusan, karena implementasi Good corporate governance (GCG) pada saat 
ini tidak hanya sekedar kewajiban, namun merupakan kebutuhan bagi setiap perusahaan dan organisasi. Pernyataan tersebut telah menegaskan bahwa perusahaan memiliki kedudukan penting dalam menjalankan perannya dalam kehidupan ekonomi dan sosial masyarakat. Belajar pada krisis perbankan di Indonesia yang dimulai pada akhir tahun 1997 bukan sematamata diakibatkan oleh krisis ekonomi, tetapi juga di akibatkan oleh belum diimplementasikannya Good corporate governance (GCG) dan etika yang melandasinya. Oleh karena itu, usaha mengembalikan kepercayaan kepada dunia perbankan Indonesia melalui restrukturisasi dan rekapitalisasi, hanya dapat berdampak secara jangka panjang apabila disertai tiga tindakan penting, yakni Ketaatan terhadap prinsip kehati-hatian, Pelaksanaan GCG, Pengawasan yang efektif dari otorisasi pengawasan bank.

Penerapan GCG ini dinilai dapat memperbaiki citra perbankan yang sempat buruk, melindungi kepentingan stakeholders serta meningkatkan kepatuhan terhadap peraturan perundang-undangan yang berlaku dan etika-etika umum pada industri perbankan dalam rangka mencitrakan sistem perbankan yang sehat. Selain itu penerapan GCG di dalam perbankan diharapkan dapat berpengaruh terhadap kinerja perbankan, dikarenakan penerapan GCG ini dapat meningkatkan kinerja keuangan, mengurangi resiko akibat tindakan pengelolaan yang cenderung menguntungkan diri sendiri atau kelompok.

Konsekuensi operasionalnya, perbankan wajib melaksanakan GCG dalam setiap kegiatan usahanya pada seluruh tingkatan atau jenjang organisasi. Bagaimana konsep GCG menjadi konsep ideal dalam tataran praktisnya, karena itu perlu adanya kesesuaian antara konsep GCG dengan prakteknya melalui sistem pengawasan.

Dalam menganalisis tahapan persiapan proses implementasi Good corporate governance (GCG) pada PT. Bank Pembiayaan Rakyat Syariah Al Makmur, teori yang diungkapkan Chinn (2000) dan Shaw (2003) adalah basis teori yang dipakai dalam melihat proses persiapan tersebut.

Pertama, membangun kesadaran (awareness Building), untuk membangun kesadaran tentang urgensi GCG ini merupakan tanggung jawab bersama, yang melibatkan semua pihak yaitu semua anggota Direksi dan Dewan Komisaris, Dewan Pengawas Syariah, serta Pemegang Saham Pengendali, dan semua karyawan. salah satu upaya ini dapat dilakukan dengan memberikan edukasi melalui seminar, lokakarya dan diskusi kelompok secara berkesinambungan.

Tahapan ini sudah dilakukan oleh pihak PT. Bank Pembiayaan Rakyat Syariah Al Makmur, namun menurut penulis untuk memperoleh hasil yang lebih maksimal, pihak BPR Syariah Al Makmur harus memberikan edukasi melalui seminar, lokakarya dan diskusi 
kelompok secara berkesinambungan dan dilakukan dengan meminta bantuan tenaga ahli independen dari luar perusahaan yang menguasai teori tentang GCG, dengan mengadirkan langsung secara bersama-sama pihak regulator dari OJK dan pihak akademisi dari perguruan tinggi yang menguasai tentang GCG, dengan melibatkan semua unsur PT. Bank Pembiayaan Rakyat Syariah Al Makmur yang nantinya semua pihak yang terkait dengan perusahaan memiliki komitmen bahwa penerapan GCG adalah sebuah kebutuhan, bukan sebatas pemenuhan peraturan saja.

Dengan begitu pihak PT. Bank Pembiayaan Rakyat Syariah Al Makmur akan lebih maksimal menyadari tentang arti penting dari GCG. Karena penerapan prinsip-prinsip GCG menjadi suatu keharusan bagi sebuah institusi, termasuk di dalamnya institusi perbankan syariah.

Kesadaran akan arti penting GCG pada PT. Bank Pembiayaan Rakyat Syariah Al Makmur sebagian sudah punya tolak ukur yaitu dengan adanya job description masing-masing. Tentu operasional dari PT. Bank Pembiayaan Rakyat Syariah Al Makmur dapat berjalan dengan baik, sehingga dapat dilihat dengan jelas sejauh mana kesadaran GCG yang telah terbangun untuk diterapkan pada manajemen PT. Bank Pembiayaan Rakyat Syariah Al Makmur.

Tanpa adanya penerapan GCG yang baik dan efektif, bank syariah tidak dapat memperkuat posisi, memperluas jaringan, dan menunjukkan kinerjanya dengan lebih baik efektif. Karena kebutuhan bank syariah akan GCG menjadi lebih serius lagi seiring dengan makin kompleksnya masalah yang dihadapi.

Kedua, tahapan yang harus ditempuh oleh pihak PT. Bank Pembiayaan Rakyat Syariah Al Makmur dalam rangka persiapan implementasi GCG adalah GCG assessment (penilaian). GCG assessment (penilaian) adalah upaya untuk memetakan kondisi perusahaan yang dilakukan oleh internal perusahaan. Langkah ini dilakukan untuk memastikan level awal penerapan GCG dan untuk mengidentifikasi langkah-langkah yang tepat guna mempersiapkan infrastruktur dan struktur perusahaan yang kondusif bagi penerapan GCG secara efektif. Berdasarkan wawancara diketahui bahwa pihak PT. Bank Pembiayaan Rakyat Syariah Al Makmur telah menyusun skala prioritas penerapan GCG yang telah dituangkan melalui rencana tindak penerapan GCG untuk implementasi disemester pertamatahun 2020.

Hal ini sejalan dengan Surat Edaran OJK nomor 13/SEOJK.03/2019, menjelaskan bahwa (OJK, 2019): Adapun jenis rencana tindak paling sedikit terdiri atas: Pemenuhan kelengkapan struktur organisasi BPRS berdasarkan modal inti, Ketersediaan pedoman dan tata tertib kerja Direksi, Dewan Komisaris, dan komite, 
Ketersediaan dan kecukupan pelaporan intern yang didukung oleh sistem informasi manajemen yang memadai, Ketersediaan kebijakan remunerasi secara tertulis bagi Direksi, Dewan Komisaris, DPS, dan pegawai BPRS.

Rencana tindak yang disusun oleh pihak PT. Bank Pembiayaan Rakyat Syariah Al Makmur untuk semester pertama sudah memenuhi ketentuan ini. Menurut penulis proses penilaian kondisi perusahaan wajib memperhatikan semua bagian baik itu struktur ataupun infrastruktur yang dibutuhkan untuk memenuhi kewajiban penerapan GCG. Salah satu aspek yang dapat mencerminkan kondisi perusahaan adalah laporan keuangan. Dari laporan keuangan inilah semua akan bisa diambil keputusan, baik itu jangka pendek maupun jangka panjang.

Laparan keuangan mencerminkan kodisi perusahaan sebenarnya, apabila kondisi finansial perusahaan baik, maka baik struktrur ataupun infrastruktur yang belum ada bisa dipenuhi. Begitupun sebaliknya, apabila kondisi finansial perusahaan sedang tidak baik, maka untuk mengambil keputusan pemenuhan rencana tindak tahap awal dapat diprioritaskan kepada hal yang tidak membutuhkan finansial yang besar. sehingga semua yang dituangkan dalam rencana tindak tahap pertama dapat dipenuhi pada saat pelaporan realisasi rencana tindak tanpa kendala apapun.

Apabila dilihat dari rencana tindak PT. Bank Pembiayaan Rakyat
Syariah Al Makmur terdapat poin penunjukan anggota Direksi yang membawahi fungsi kepatuhan, menurut penulis poin ini seharusnya tidak dimunculkan pada semester pertama, dibutuhkan pertimbangan yang matang untuk memutuskannya, karena untuk posisi ini membutuhkan biaya yang besar, yang melekat padanya fasilitas diantaranya tunjangan, mobil dinas, rumah dinas, team kerja dan lain-lain, sehingga pihak perusahaan harus mengalokasikan biaya yang besar, ditambah untuk mengisi posisi direktur kepatuhan juga membutuhkan serangkaian tes yang panjang serta membutuhkan waktu lama.

Ketiga, tahapan yang harus ditempuh dalam rangka mempersiapkan penerapan Good corporate governance (GCG) adalah Manual Building (penyusunan pedoman). Manual Building (penyusunan pedoman) merupakan penyusunan pedoman implementasi Good corporate governance (GCG) setelah langkah GCG Assessment dilakukan. Berdasarkan hasil pemetaan tingkat kesiapan perusahaan dan upaya identifikasi prioritas penerapannya, penyusunan manual atau pedoman implementasi Good corporate governance (GCG) dapat dibuat.

Sejauh informasi yang penulis kumpulkan, dapat diketahui bahwa pihak PT. Bank Pembiayaan Rakyat Syariah Al Makmur masih dalam proses menyusun pedoman implementasi secara lebih terperinci. Tentunya dalam proses penyusunan ini secara 
standarisasi disesuaikan dengan pedoman implementasi GCG yang secara umum tertuang dalam POJK. Pihak yang dilibatkan dalam penyusuanan pedoman implementasi GCG adalah Dewan Komisaris, Direksi dan Pejabat Eksekutif yang membawahi fungsi Kepatuhan dan Manajemen Risiko.

Pihak PT. Bank Pembiayaan Rakyat Syariah Al Makmur sangat yakin bahwa pedoman implementasi GCG ini akan membantu melahirkan tata kelola perusahaan yang baik. Karena untuk mencapai sesuatu tentunya akan lebih mudah jika kita telah memiliki pedoman yang jelas untuk pelaksanaannya. Bahkan pihak PT. Bank Pembiayaan Rakyat Syariah Al Makmur secara bersama-sama telah berkomitmen yang nantinya akan tertuang dalam pedoman implementasi GCG akan memberi sanksi apabila ada yang melanggar pedoman tersebut.

Adapun yang menjadi kendala terbesar pihak PT. Bank Pembiayaan Rakyat Syariah Al Makmur dalam persiapan pelaksanan GCG ini adalah persoalan infrastruktur, yang apabila semua ketentuan yang tertuang dalam Peraturan Otoritas Jasa Keuangan Nomor 24/P0JK.03/2018 dijalankan maka akan membutuhkan infrastruktur yang tidak sedikit yang erat kaitannya dengan finansial. Kendatipun demikian optimisme yang dimiliki oleh pihak PT. Bank Pembiayaan Rakyat Syariah Al Makmur terhadap pelaksanaan GCG sangat tinggi, terbukti dengan komitmen pemberian sanksi terhadap pelanggaran yang terjadi dalam pelaksanaan GCG

Menurut penulis, kendala ini timbul sebagai akibat belum maksimalnya kesadaran yang dibangun tentang arti penting GCG, yang berdampak pada proses pemetaan konsisi perusahaan yang kurang maksimal serta pedoman pelaksanaan GCG yang belum selesai, dan untuk mengatasi itu semua maka pihak PT. Bank Pembiayaan Rakyat Syariah Al Makmur BPR Syariah Al Makmur harus memaksimalkan pemberikan edukasi melalui seminar, lokakarya dan diskusi kelompok secara berkesinambungan dan dilakukan dengan meminta bantuan tenaga ahli independen dari luar perusahaan yang menguasai teori tentang GCG yaitu dari pihak regulator dan pihak akademisi, sehingga permasalahan ini dapat terselesaikan.

\section{PENUTUP}

Berdasarkan temuan penelitian terkait Persiapan PT. Bank Pembiayaan Rakyat Syariah Al-Makmur dalam penerapan Good Corporate Governance (GCG) didapat beberapa kesimpulan bahwa untuk tahap Awareness Building (membangun kesadaran), sudah dilakukan dengan baik, sesuai dengan teori Chinn (2000) dan Shaw (2003) tetapi harus dimaksimalkan lagi dengan cara memberikan edukasi melalui seminar, lokakarya dan diskusi kelompok secara berkesinambungan sehingga semua unsur yang terlibat memiliki pemahaman dan kesadaran 
yang sama tentang pentingnya pelaksanaan GCG. Salah satunya dengan menghadirkan langsung secara bersama-sama pihak regulator dari OJK dan pihak akademisi dari perguruan tinggi yang menguasai detail tentang GCG, dengan melibatkan semua pihak terkait pada PT. Bank Pembiayaan Rakyat Syariah Al Makmur.

Tahap GCG Assessment (penilaian), yang dilakukan oleh internal perusahaan sudah sesuai dengan teori Chinn (2000) dan Shaw (2003), tetapi dalam menentukan skala prioritas harus memperhatikan kondisi internal perusahaan sehingga struktur dan infrastruktur tidak lagi menjadi kendala dalam memenuhi rencana tindak pada implementasi GCG. Tahap Manual Building (penyusunan pedoman), pihak PT. Bank Pembiayaan Rakyat Syariah Al-Makmur belum menyelesaikan pedoman GCG sebagai satu kesatuan rujukan GCG.

Secara keseluruhan, persiapan yang dilakukan oleh pihak PT. Bank Pembiayaan Rakyat Syariah Al-Makmur sudah baik, hanya saja perlu dimaksimalkan lagi, dengan harapan bahwa apabila persiapan dilakukan dengan maksimal, maka hasil dari pelaksanaan nantinya juga akan sangat baik dan sesuai dengan ketentuan yang berlaku, sehingga PT. Bank Pembiayaan Rakyat Syariah Al-Makmur akan semakin berkembang.

\section{DAFTAR KEPUSTAKAAN}

Abdullah, M. A. (2010). Corporate
Governance Perbankan Syariah di Indonesia. Jogjakarta: Ar-Ruzz Media.

Arifin, Z. (2005). Teori Keuangan dan Pasar Modal. Yogyakarta: Ekonisia.

Makmur, BPR Syariah Al (2009). Profil BPRS Al Makmur, Payakumbuh. BPR Syariah Al Makmur.

Machmud, A., \& Rukmana. (2010). Bank Syariah: Teori, Kebijakan, dan studi empiris di Indonesia. Jakarta: Erlangga.

Moleong, L. J. (2007). Metodologi Penelitian Kualitatif. Bandung: PT. Remaja Rosdakarya Offset.

Sugiyono. (2012). Memahami penelitian kualitatif. Bandung: Alfabeta.

Usman, R. (2014). Aspek Hukum Perbankan Syariah di Indonesia. Jakarta: Sinar Grafika.

Zarkasyi, W. (2008). Good Corporate Governance pada Badan Usaha Manufaktur, Perbankan dan jasa Keuangan Lainnya. Bandung: Alfabeta.

BI. (2005, November), Transparansi Kondisi Keuangan BPR Syariah. https://www.ojk.go.id/

BI. (2006, Januari). Peraturan Perbankan.

https://www.bi.go.id/id

BI. (2007, Desember). Pelaksanaan Prinsip Syariah dalam Kegiatan Penghimpunan Dana dan Penyaluran Dana serta Pelayanan Jasa. https://www.ojk.go.id

BI. (2010, April). Peraturan Perbankan. https://www.bi.go.id

BI. (2011, November). Batas Maksimum Penyaluran Dana Bank Pembiayaan 
Rakyat

https://www.ojk.go.id

Furqani, A., \& Andini, I. Y. (2013). Implementasi Good Corporate Governance (GCG) pada BUMD Kabupaten Sumenep (studi pada PT. Bank Pembiayaan Rakyat Syariah (BPRS) Bhakti Sumekar Sumenep). Performance Bisnis \& Akuntansi, 67.

Governance, K. N. (2004, Januari). Pedoman Good Corporate Governance Perbankan Indonesia. Komite Naisonal Kebijakan Corporate Governance.

Governance, K. N. (2011). Pedoman Umum Good Governance Bisnis Syariah. Komite Nasional Kebijakan Governance.

Harjanti, A. E. (2018). Analisis tahap persiapan dan Tahap Implementasi Good Corporate Governance pada Bank Perkreditan Rakyat (Studi pada PT BPR Mitra Budikusuma Mandiri Kudus). Electonic thesis \& Dissertasi (ETC) Gajah Mada University

Junusi, R. E. (2012). Implementasi syariah governance serta implikasinya terhadap reputasi dan kepercayaan Bank Syariah. AlTahrir, 113.

KBBI. (t.thn.). Diambil kembali dari https://kbbi.web.id/siap

Khairunnisa, T. (2018). Analisis Pelaksanaan Good Corporate Governance Pada Bank Pembiayaan Rakyat (BPR) Syariah (Studi Pada PT BPR Syariah Margirizki Bahagia). Electonic thesis \& Dissertasi (ETC) Gajah Mada University, 95.
OJK. (2015, Desember). Produk dan Aktivitas Bank Syariah dan Unit Usaha Syariah. https://www.ojk.go.id

OJK. (2016, November). Rencana Bisnis Bank Perkreditan Rakyat dan BankPembiayaan Rakyat Syariah. https://www.ojk.go.id

OJK. (2018, Desember). Tata -Kelola bagi Bank Pembiayaan Rakyat Syariah https://www.ojk.go.id

OJK. (2018, Desember). Penerapan Manajemen Risiko bagi Bank Pembiayaan Rakyat-Syariah. https://www.ojk.go.id

OJK. (2019, Juni). Penerapan Tata Kelola Bagi Bank Pembiayaan Rakyat Syariah. https://www.ojk.go.id

Rahmat, B. Z. (2017). Optimalisasi peran Dewan Pengawas Syariah dalam pelaksanaan Good Corporate Governance di BPRS Harum Hikmahnugraha. Jurnal Ekonomi dan Keuangan Syariah, 294.

Siswanti, I. (2016). Implementasi Good Corporate Governance pada kinerja bank syariah. Jurnal Akuntansi multiparadigma, 322.

Syukron, A. (2013). Good Corporate Governance di Bank Syariah. Economic: Jurnal Ekonomi dan Hukum Islam, 80-81. 